\title{
Strategic Litigation: the Problem of the Abuse of Law and Other Critiques
}

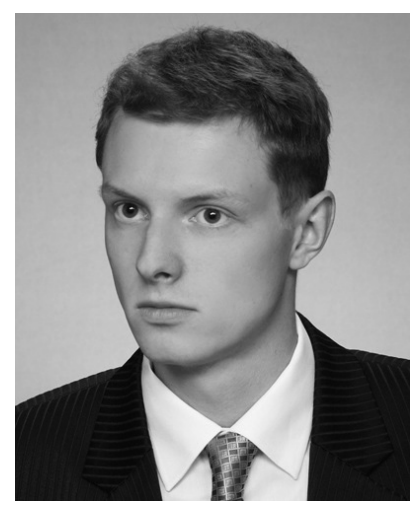

\section{kukasz Mirocha}

PhD in law, barrister. Interested in modern political philosophy, churchstate relations and bioethical issues.

$\triangle$ adwokat.mirocha@gmail.com

https://orcid.org/oooo-0002-1498-2960

\author{
Key words: strategic litigation, judicial activism, judicial passivism, \\ international courts, abuse of law \\ https://doi.org/10.32082/fp.v3i53.211
}

The word "abuse" seems to be made of two parts. The root "use" stands for "to take advantage of something" - implicitly - in a casual, normal way. The prefix "ab", however, changes the meaning of the root, indicating that it concerns something beyond the casual, normal usage. ${ }^{1}$ The comparison of any random definition of strategic litigation with a simple semantic analysis of the term "abuse" immediately gives rise to a view that strategic litigation can be easily described as a kind of abuse of the practice of litigating. This notion arises because the primary purpose of strategic litigation does not refer to the interest of the party to the proceedings (like in conventional litigation); instead, it is aimed at "bringing

1 The situation looks similar when it comes to the Polish equivalent of "abuse" - word "nadużycie", which also encompasses core-part "użycie" and prefix "nad", that adds a negative connotation to the whole construction. social change", always deprived of any evaluation. ${ }^{2}$

In my opinion, the observation above is hardly the only reason supporting the necessity of investigating possible critiques of the strategic litigation. The contemporary literature devoted to this institution presents certain instances of its critique; nevertheless, it provides us with possible allegations or doubts addressed exclusively from the perspective of strategic litigation's proponents (or proponents of aims of strategic

2 See e.g.: Strategic Litigation Impacts. Insights from Global Experience, New York 2018, p. 31, accessible: https://www.justiceinitiative.org/ publications/strategic-litigation-impacts-insights-global-experience (last accessed 31.5.2019); Interview with Martin O`Brien, [in:] S. Hansen, Strategic litigation, New York 2018, p. 11; Public Law Project: Guide to Strategic Litigation, p. 5, accessible: https://publiclawproject. org.uk/wp-content/uploads/data/ resources/153/40108-Guide-to-Strategic-Litigation-linked-final_1_8_ 2016.pdf (last accessed 31.5.2019). 
litigation). ${ }^{3}$ As a result, such a criticism has an ostensible character, focusing mostly on the inefficiency of strategic litigation, rather than on more down-toearth sceptical reflection on ideas standing behind the whole concept.

The first impression regarding the possibly abusive character of strategic litigation plays a crucial role in the present paper; nevertheless, other probable points of criticism are voiced in further parts of the paper. Firstly, the paper presents the concept of strategic litigation, particularly its meaning, history and some dilemmas posed by the proponents of this concept. Furthermore, I will demonstrate the stages of development of the construction of the abuse of rights. Third part of the paper is an attempt to state certain general conclusions on the applicability of the argument of law abuse as pertains to strategic litigation, whereas the fourth part deals with further possible points of criticism of the concept.

\section{Strategic litigation}

Adam Bodnar, currently the Commissioner for Human Rights in Poland, and formerly a human rights activist, in one of his articles assures that it is the client's interests that play the primary role during strategic litigation. ${ }^{4}$ This statement seems to be at odds with the distinctive feature of strategic litigation, whose emphasis is put on the outer effects. Should his statement be true, strategic litigation would not be distinguishable from non-strategic forms of litigating. It goes without saying that every legal proceeding concerning a socially sensitive issue could have far reaching effects going beyond the legal situation of the parties involved in a particular dispute. From this perspective, the quoted opinion should be treated only as a form of a euphemism concealing some less

3 See e.g.: Interview with Martin O'Brien, [in:] S. Hansen, Strategic litigation, p. 14; H. Duffy, Strategic Human Rights Litigation: 'Bursting the Bubble on the Champagne Moment' (inaugural lecture given on 13 March 2017 at Leiden University), p. 8, 13, accessible: https://openaccess.leidenuniv. $\mathrm{nl} /$ handle/1887/59585 (last accessed 31.5.2019)

4 A. Bodnar, W poszukiwaniu precedensów - litygacja strategiczna w praktyce Helsińskiej Fundacji Praw Człowieka, [in:] Precedens $w$ polskim systemie prawa, ed. A. Śledzińska-Simon, M. Wyrzykowski, Warszawa 2010, p. 141. elevated facts about strategic litigation. The following part of the paper aims to verify this bitter observation.

\subsection{The concept of strategic litigation}

The subject literature, especially widespread guides easily accessible via the Internet, offer a variety of names to refer to the same phenomenon. James A. Goldston enumerates the following: "public interest litigation", "human rights litigation", "test case litigation", "impact litigation", "social action litigation", "social change litigation" and last but not least: "strategic litigation". Some of the expressions are indeed meaningful - they focus on the aims of litigation (impact, human rights, social change) or methods being applied (test case litigation, social action litigation). 6 "Human rights lawyering"7 could be regarded as a related institution, though it is not necessarily associated with applying any special strategies or achieving far-reaching goals, which is characteristic for strategic litigation.

As outlined above, strategic litigation could be defined as designed to achieve ends reaching beyond success in a particular legal dispute, aiming to obtain some extra benefits for a wider circle of stakeholders. ${ }^{8}$ In this sense, strategic litigators try to turn the court proceedings which traditionally involve two parties $^{9}$

5 J. A. Goldston, Public Interest Litigation in Central and Eastern Europe: Roots, Prospects, and Challenges, "Human Rights Quartely”vol. 28/2006, p. 496.

6 This description is particularly interesting when we take into account that the overwhelming majority of strategic litigation is run directly or supported indirectly by non-governmental organisations. This leads to the conclusion that modern society could be exclusively identified with a non-governmental sector. On the critique of this stance see P. S. Załęski, Neoliberalizm i społeczeństwo obywatelskie, Torun 2012, p. 149-212.

7 See e.g.: R. J. Wilson, J. Rasmusen, Promoting Justice. A Practical Guide to Strategic Human Rights Lawyering, Washington 2001, accessible: http://www.sbdp.org.br/arquivos/ material/280_IHRLG_-_International_Human_Rights_Law_ Group_-_Promoting_justice_-_a_pratical_guide_to_strategic_HR_lawyering.pdf (last accessed 31.5.2019).

8 See J. A. Goldston, Public Interest Litigation in Central and Eastern Europe, p. 496.

9 In the contexts of strategic litigation, in the overwhelming majority of cases those are: citizen as claimant and government as defendant. 
into actio popularis or a collective complaint. Bearing this in mind, strategic litigation's proponents usually distinguish two groups of pursued goals: 1) intra-legal objectives, concerning the interpretation, application or content of law, 2) extra-legal objectives, which for institutions. Strategic litigation can take the form of direct pleading before the courts, when lawyers provided by a non-governmental organisation represent one of the parties, or indirect support e.g. delivering amicus curiae opinions. ${ }^{12}$

\section{In this sense, strategic litigators try to turn the court proceedings which traditionally involve two parties into actio popularis or a collective complaint.}

example include raising social awareness of a discussed problem or exerting pressure on political actors. ${ }^{10}$ The authors of the paper delivered under the auspices of the Open Society Justice Initiative, an organisation supported by George Soros, leading in the area of strategic litigations, enumerates three possible effects of strategic litigation: 1) material outcomes that include direct changes such as financial compensation, transfer of property, or prosecution of perpetrators, 2) instrumental impacts that include changes in policy, law, jurisprudence, or institutions, 3) non-material impacts e.g. changes of public attitude, particularly the opinions of policymakers, teachers, police officers, but also ordinary citizens. ${ }^{11}$

The next feature which could be - without a doubt associated with contemporary strategic litigations is that they are mostly run by specialised non-governmental organisations. Numerous handbooks about strategic litigation emphasize the necessity of engaging highly specialised and personally involved lawyers and other supporters of the case raised in a given instance of the litigation, which seems to be self-evident. As a result, strategic litigation is described as an action taking place between social movements and state

10 See Equinet Handbook on Strategic Litigation, Brussels 2017, p. 9, accessible http://equineteurope.org/2019/02/21/strategic-litigation-handbook/ (last accessed 1.6.2019); Public Law Project: Guide to Strategic Litigation, p. 5.

11 Strategic Litigation Impacts. Insights from Global Experience, p. 43.
As a strictly target-oriented activity undertaken by specialised representatives, strategic litigation is very often accompanied by other forms of influence on the contested problem. Proponents of strategic litigations claim that this form of enforcing social changes could be the most efficient when conducted simultaneously with press coverage and other media campaigns, lobbying, and legislative advocacy. Cummings and Rhode observe that:

\begin{abstract}
"A key lesson from law and social change research is the importance of situating litigation within broader political campaigns - of using it as means to an end, rather than an end in itself. Unlike early models of public interest litigation in which lawyers looked for test cases that could establish important principles, this approach explores multiple strategies from the outset, including not just lawsuits but also policy, organizing, and media initiatives." ${ }^{\text {13 }}$
\end{abstract}

Considering the fact that it is the outlining of a social problem that is the sole purpose of at least some of the proceedings initiated by strategic litigators, even losing a single proceeding could be perceived by them as successful. Losing of a case could provide the suf-

12 A. Bodnar, W poszukiwaniu precedensów, p. 142.

13 S. L. Cummings, D. L. Rhode, Public Interest Litigation: Insights from Theory and Practice, "Fordham Urban Law Journal “ vol. XXXVI/2009, p. 615. See also Strategic Litigation Impacts. Insights from Global Experience, p. 33. 
ficient basis to draw public attention to the problem in question. ${ }^{14}$

The proponents of strategic litigations often proclaim themselves as defenders of the marginalized, the poor, or social outcasts. ${ }^{15}$ This view could be, however, all around the world. ${ }^{17}$ Due to different circumstances, strategic litigation could vary in exerted impact: "while strategic litigation may be more effective in democratic societies, it may be more significant in illiberal societies where it is often one of the few forms of advocacy

\section{The proponents of strategic litigations often} proclaim themselves as defenders of the marginalized, the poor, or social outcasts.

perceived as contrasting with the fact that organisations specialised in strategic litigations are very often forced to initiate kinds of enrolments to find persons interested in becoming a party in court proceedings brought against a government. ${ }^{16}$ Naturally, in the circumstances of an oppressive regime violating basic civil rights, where a citizen suing a government is able to predict that he or she will inevitably become a victim of the government's vengeance, such an approach is legitimate and hardly surprising. Nevertheless, it is difficult to equate such situations with the presumed position of a defender of marginalised groups, who need to recruit parties interested in initiating a legal action, acting in the conditions of a liberal democracy, in which the right to a fair trial is ensured for everyone. Adding two assumptions to this reasoning: 1) if I am oppressed, I am looking for help, 2) if I am oppressed and countermeasures are available to me, I use them, it will allow us to raise the question of whether strategic litigators are the real servants of the victims of oppression, if it is necessary for them to recruit so called "friendly victims".

Leaving aside these doubts, it should be admitted that the popularity of strategic litigation is increasing

14 A. Bodnar, W poszukiwaniu precedensów, p. 125, 140.

15 A. Bodnar, W poszukiwaniu precedensów, p. 161; Strategic Litigation Impacts. Insights from Global Experience, p. 36.

16 See e.g. https://kph.org.pl/poszukiwane-pary-jednoplciowe-do-litygacji-strategicznej/ (last accessed 1.6.2019). permitted". ${ }^{18}$ However, as James A. Goldston noticed after inquiring into the status of strategic litigation in Central and Eastern Europe, this institution is seen very positively in newly established democracies. ${ }^{19}$ These observations move us to the issue of the origins of strategic litigations.

\subsection{History and examples}

Strategic litigation, as an institution relying on the power of the courts, is generally linked with the common law system. It is also believed that this phenomenon has quite a short history, reaching back no longer than the past thirty years. Both statements are incorrect in a way.

Referring to the first statement, it has to be noticed that it is mainly thanks to the development of international courts, such as the ECHR or CJEU, that strategic litigation gained significance also beyond common law countries. Generally, it is presupposed by strategic litigators that each legal dispute began before national courts, if not won there, would find its continuation before international bodies. NGOs recruiting parties to the proceedings inform that their aim is to go through all domestic instances just to open the door to pleading before international courts.

17 H. Duffy, Strategic Human Rights Litigation, p. 1.

18 Strategic Litigation Impacts. Insights from Global Experience, p. 17.

19 J. A. Goldston, Public Interest Litigation in Central and Eastern Europe, p. 493. 
When it comes to the second statement (concerning the history of strategic litigation), one should be aware that first proceedings aimed generally at procuring changes (not only to win a case for the represented party), were brought to courts already in the $18^{\text {th }}$ century. According to the literature devoted to this issue, litigations provoked by the British anti-slavery movement, including the famous Somerset $v$. Stewart judgement delivered in 1772, or The Society for Suppression of Vice efforts promoting public morality with the usage of a legal path, had such a character. ${ }^{20}$ regard to highly disputable issues, for example in cases concerning surrogate motherhood. ${ }^{23}$

Supporters of strategic litigation tend to portray it as an institution that could be equally useful for leftwing and right-wing activists. ${ }^{24}$ It could be surprising when compared with their other claims, especially those concerning "social change" seen as the main purpose of strategic litigation. The pursuit of social change seems to be an exclusively leftist ideal, whereas right-wingers make efforts rather to preserve the current state of affairs. ${ }^{25}$ Still, to do so, taking advantage

\section{The pursuit of social change seems to be an exclusively leftist ideal, whereas right-wingers make efforts rather to preserve the current state of affairs.}

Strategic litigation had its revival in the $20^{\text {th }}$ century, when it initiated many positive social changes. One of the most remarkable and uncontroversial examples is Brown v. Board of Education of Topeka, decided by the US Supreme Court in 1954, which brought the practice of racial segregation in the United States to an end.

More recent history also delivers countless examples of the positive effects of strategic litigations. Significant changes were brought thanks to cases before Indian, Colombian or South African supreme courts. ${ }^{21}$ In Europe, cases concerning the desegregation for Roma students in Czech and Hungarian schools were exceptionally significant (e.g. D. H. v. Czech Republic). ${ }^{22}$ They can be undoubtedly considered as successes of strategic litigation. In contrast to these uncontroversial cases, strategic litigation nowadays is used with

20 See Strategic Litigation Impacts. Insights from Global Experience, p. 31; Public Law Project: Guide to Strategic Litigation, p. $6-7$.

21 H. Duffy, Strategic Human Rights Litigation, p. 3.

22 Application no. 57325/00, judgement by European Court of Human Rights delivered on 13 November 2007 (Grand Chamber). of some instruments developed in the field of strategic litigations could prove effective. It is worth indicating the activity of the European Centre for Law and Justice $^{26}$ as an example of exercising this strategy in cases regarding religious freedom or surrogate motherhood. Lawyers involved in the ECLJ pleading before ECHR and other bodies, or presenting amicus curiae opinions, defend the idea of human rights based on natural law, which could be seen as a sort of a counter-strategic litigation activity.

\subsection{Exemplary strategies}

Strategic litigation guides accessible via the Internet and provides us with a comprehensive system of step-by-step advices, teaching how to select a case, and then commence, conduct and win a litigation.

23 See $Ł$. Mirocha, „Macierzyństwo zastępcze” w aktualnym orzecznictwie Europejskiego Trybunału Praw Człowieka, „Prawo w działaniu” vol. 34/2018.

24 Public Law Project: Guide to Strategic Litigation, p. 6-7.

25 See R. Scruton, Co znaczy konserwatyzm, transl. T. Bieroń, Poznań 2014.

26 Official web page: https://eclj.org/institutions (last accessed 1.6.2019). 
Hints presented in handbooks are very detailed, each stage of legal proceedings and extra-legal activities linked with strategic litigation are deeply analysed. For example, it concerns choosing an appropriate case (from the perspective of the presupposed aim), recruiting parties, collecting funds, developing a press and media strategy. One can easily find both guides addressed to amateurs - wannabe activists, and handbooks targeted at improving the professional skills of lawyers dealing with strategic litigation. Armed with such guides, any person can grasp what strategic litigation is all about. An analysis of handbooks allows us to realize that strategic litigation is hardly mentioned Open Society Justice Initiative, informs via its official web page that it has spent over 15 billion dollars "focused on supporting people who are trying to make their communities fairer, freer, and more harmonious" ${ }^{29}$ This sum includes 35 million dollars spent on strategic litigation activity. ${ }^{30}$

The next advice I would like to discuss has been signalled in the previous part of the paper: strategic litigations require a "friendly victim", or a person who is ready to become a party to the proceedings and go through all domestic instances until the case is referred to the international courts. What is particularly interesting is that the preparations to stra-

\section{Contrary to the stereotypical image of NGOs' activity,} as mainly based on volunteers' support, strategic litigation relies on professionals, which entails costs.

an activity performed by amateur, undisciplined idealists; instead, it is a serious undertaking conducted by committed, professional officials gathered around NGOs. To quote the content of the guides in this paper would be redundant; however, bearing in mind the aims of the paper, it is important to draw attention to the selected recommendations included in them.

First of all, each handbook pays a lot of attention to the sources of financing every such undertaking. Strategic litigators are aware that carrying this sort of activity is - to put it simply - an expensive task. Contrary to the stereotypical image of NGOs' activity, as mainly based on volunteers' support, strategic litigation relies on professionals, which entails costs. ${ }^{27}$ Taking into account that the desirable social changes planned as an effect of litigations are rarely widely supported, strategic litigators are advised to search for funds abroad. ${ }^{28}$ For example, the Open Society Foundations, an organisation associated with the above-

27 Public Law Project: Guide to Strategic Litigation, p. 29.

28 J. A. Goldston, Public Interest Litigation in Central and Eastern Europe, p. 525-526. tegic litigations presuppose the necessity of involving more than one potential party to the proceedings, ${ }^{31}$ as one of the represented persons may drop the case prematurely, or opt for a settlement with the sued government. ${ }^{32}$ In my opinion, such an approach, once again, raises questions as to whose interests is strategic litigation devoted to.

Timing is also a crucial issue for strategic litigators. The quoted handbooks warn against commencing the dispute too early, when society is "not ready yet" for targeted changes. In the worst case scenario, a strategic litigator risks the so called negative precedent, political backlash, or even social resistance. ${ }^{33} \mathrm{To}$ avoid these risks or limit their impact, strategic litigations are proceeded step-by-step. Such an attitude

29 https://www.opensocietyfoundations.org/ (last accessed 2.6.2019).

30 Strategic Litigation Impacts. Insights from Global Experience, p. 23.

31 See e.g. announcement in the footnote no. 16, above.

32 A. Bodnar, W poszukiwaniu precedensów, p. 153.

33 Equinet Handbook on Strategic Litigation, p. 31. 
can be observed in cases dealing with the problem of same-sex partnerships ${ }^{34}$ or surrogate motherhood ${ }^{35}$ in domestic legal systems which do not accept them. The claimants do not try to directly challenge binding national regulations; instead, they point to their negative effects and, at the same time, try to circumvent them by forcing national authorities to recognize the legal consequences of decisions and acts adopted by foreign bodies using other legislation. After the issue of recognizing the legal consequences of using foreign legal regulations is overcome, one can directly attempt to introduce new institutions in the domestic legal system which are similar to foreign ones.

\subsection{Constraints of strategic litigation: inner perspective}

The literature regarding the problem, and even widespread handbooks on strategic litigation, almost always voice criticism towards the institution. It is hard to decide whether the reason for placing such a critique by the proponents of the whole concept is to fulfil the scholarly requirement of presenting a balanced point of view, or courtesy to other authors. The fact is that commonly presented caveats do not change their authors' positive evaluation of strategic litigation. Two popular strands of such a "critique" are presented below: inefficiency and unavailability. ${ }^{36}$

Firstly, as noted above, the proponents of strategic litigation are aware that even the winning of specific cases does not spontaneously lead to social change. ${ }^{37}$ It is the basic drawback of strategic litigation, the answer to which is to conduct other activities aimed

34 See e.g. Orlandi and Others v. Italy, ECHR 2017, application no. 26431/12; 26742/12; 44057/12 and 60088/12).

35 See P. Mostowik, Problem rejestracji w polskich aktach urodzenia pochodzenia dziecka od "rodziców jednopłciowych" na tle orzecznictwa sądów administracyjnych w 2018 r., Warszawa 2019, accessible https://iws.gov.pl/wp-content/ uploads/2019/03/IWS-P.-Mostowik-problem-rejestracji.pdf (last accessed 2.6.2019).

36 I omit technical problems raised by strategic litigators, such as the issue of financial problems of NGOs supporting this undertaking, or the problem of the identification of lawyers with the cases carried out by them.

37 Interview with Martin O'Brien, [in:] S. Hansen, Strategic litigation, p. 14. at improving the social consciousness, or the lobbying of political actors at the same time. As Cummings and Rhode admit: "litigation cannot itself reform social institutions". ${ }^{38}$ Claims that funds sacrificed for strategic litigation could be spent in a more efficient way are also raised. However, in this group of problems, another one seems to be most troublesome for supporters of the conception: the risk of creating a "negative precedent", which means losing the case and, as a result, reinforcing legal provisions or social attitudes towards the challenged legislation. The most significant example of this phenomenon is the Plessy $v$. Ferguson judgement, issued by the American Supreme Court in 1896, that started the infamous practice of "equal but separate" in the United States. ${ }^{39}$ Furthermore - as Cummings and Rhode indicate in their analysis - even the victory in a court can bring negative effects affecting other litigations - it can likely provoke an institutional backlash. They illustrate this thesis stating that:

\begin{abstract}
"Courthouse victories fueled a conservative reaction seeking to limit federal authority over civil rights and civil liberties, economic and environmental regulation, and social welfare. As the right gained power in the 1980s and 1990s, national governance structures were reshaped. An increasingly conservative federal judiciary became less hospitable to the claims of liberal public interest groups." ${ }^{40}$
\end{abstract}

Adam Bodnar adds that the resistance of the lawmaker could occur not only in the institutional sphere (shortening procedural opportunities for strategic litigators), but also take the form of a parliamentary majority disapproving judicial solutions and trying to "overrule" it by enacting appropriate substantive law. ${ }^{41}$ The story of tensions between the judiciary branch and legislator caused by the Employment Division $v$. Smith judgement delivered by the American Supreme Court in 1990 is a great example of such consequences; another one is the recent action of the Polish Attorney

38 S. L. Cummings, D. L. Rhode, Public Interest Litigation, p. 604. 39 H. Duffy, Strategic Human Rights Litigation, p. 8.

40 S. L. Cummings, D. L. Rhode, Public Interest Litigation, p. 607. 41 A. Bodnar, W poszukiwaniu precedensów, p. 155. 
General, who tried to question (before the Constitutional Tribunal $)^{42}$ the provisions by virtue of which the Polish Supreme Court sentenced the man accused of purportedly illegitimate refusal of service to an LGBT association. ${ }^{43}$

The criticism towards the accessibility of strategic litigation for ordinary citizens has at least three aspects. First of all, it should be noticed that legal proceedings are generally expensive, thus limiting the number of potential claimants. ${ }^{44}$ The fact that in most cases strategic litigations are led by NGOs makes little difference, because NGOs tend to select the most interesting (from their perspective) cases rather than associates by the government. ${ }^{46}$ Such an approach of the state can effectively discourage potential claimants from initiating proceedings; however this sort of risk seems to be most common in the case of third-world countries or oppressive regimes.

Adam Bodnar claims that "the legislator must accept that his role has changed and that the courts would play an increasingly important role in shaping legal provisions"; he adds that "it would be harmful if the legislator did not comply with the will of the courts". ${ }^{47}$ This opinion may sound tempting and even convincing

\section{Such an approach of the state can effectively} discourage potential claimants from initiating proceedings; however this sort of risk seems

to be most common in the case of thirdworld countries or oppressive regimes.

provide help for the people whose needs are the most urgent. ${ }^{45}$ Secondly, litigations usually last long, which also affects their availability (as an effective instrument), because the party in need would rather resign from a lawsuit if a few years of the duration of a trial are anticipated. The next risk connected with the issue of the availability of litigations raised by proponents of the institution are the potential repressions of claimants, their families or even a wider group of

42 Case no. K 16/17.

43 See $Ł$. Mirocha, Polskie orzecznictwo w perspektywie wyroku w sprawie Masterpiece Cakeshop, „,Forum Prawnicze” vol. 2 (46)/2018.

44 H. Duffy, Strategic Human Rights Litigation, p. 2, 4-5.

45 Of course, there are NGOs specialised in providing legal help for the poor regardless of the sort of the case, but the concept of strategic litigation presupposes the selection of cases based on more strict criteria, just to achieve previously defined aims. for some; however, it is difficult to reconcile with the basic principle of the legal order, such as the separation and cooperation of powers, sometimes equated with the checks-and-balances system. The quoted opinion favours the courts and judicial power, which abuses the entire idea of the division of powers. In order to conclude these remarks, it should be remembered that strategic litigators often portray themselves as the defenders of rights. Though it could be true in some cases, the analysis of their activity as far as morally sensitive issues are concerned leads to a different evaluation - they are the designers of new rights, based on often unclear, open-texted provisions of human rights treaties interpreted in various ways. In connection with the abovementioned remarks, it provokes the question

46 Strategic Litigation Impacts. Insights from Global Experience, p. 66.

47 A. Bodnar, W poszukiwaniu precedensów, p. 154-155. 
whether social changes driven in the described way have any democratic legitimation, or perhaps they are only the realisation of the expectations of determined NGOs' officers assisted by skilful lawyers.

\section{Abuse of law}

According to an old Latin sentence: neminem laedit qui suo iure utitur. The maxim reflects one of the basic legal principles, which is - unfortunately - increasingly questioned due to the fact of misusing granted rights. As in the case of almost every argument based on a Latin sentence, we can indicate a counter-maxim, i.e. sic utere iure tuo ut alterum non laedas or nemo expropria turpitudine commodum capere potest, that sum up the essence of the modern principle of prohibition of the abuse of rights (or law).$^{48}$ The following part of the paper attempts to present sources and the the course of law's development, the concept spread among other fields of civil law and other branches of law, earning the status of its basic principle. ${ }^{49}$

The concept of the abuse of rights is characteristic for civil law legal systems; it was also acknowledged in socialist legal systems. Neither the common law nor the legal systems of Nordic countries recognize it. ${ }^{50}$ There are several reasons of resistance to the concept when it comes to common law countries. Their legal practice focuses on objective circumstances, not on the intentions of the parties of legal relationship. The uncertainty concerning the results of application of this institution, and even the principles of its application are another reason for its rejection. ${ }^{51} \mathrm{It}$ is sometimes suggested, however, that common law acknowledges the concept of the abuse of law, or tries to reach its effects in other ways. The use of sophisti-

\section{The concept of the abuse of rights is characteristic for civil law legal systems; it was also acknowledged in socialist legal systems.}

development of this institution in three branches of law, in which strategic litigation can frequently occur. The order of the following part illustrates the stages of development of the abuse of the institution of law.

\subsection{Domestic legal systems}

The modern history of the institution under analysis begins in the mid-19 $9^{\text {th }}$ century in France. The concept of the abuse of rights (and its prohibition) was worked out in the area of property law, especially regarding neighbourhood disputes concerning the malicious construction of useless fences or chimneys. During

48 A. Kiss, Abuse of Rights, p. 1, accessible: https://files.pca-cpa. org/pcadocs/bi-c/1.\%20Investors/4.\%20Legal\%20Authorities/ CA301.pdf (last accessed 9.6.2019); R. Kolb, Principles as Sources of International Law (with Special Reference to Good Faith), "Netherlands International Law Review" vol. 53.1/2006, p. 18. cated aspects of the tort law may serve as one example; another one would be interpreting situations in which civil law would recognise the abuse of one's rights as if there were no rights at all, because a perpetrator's behaviour extended the potential scope of the application of the rights. ${ }^{52}$

Julio Cueto-Rua enumerates four criteria (concepts) of recognising when rights are misused: 1) when they are exercised for the purpose of causing dam-

49 J. Cueto-Rua, Abuse of Rights, "Louisiana Law Review" vol. 35.5/1975, p. 965, 967, 979-981.

50 A. Lenaerts, The General Principle of the Prohibition of Abuse of Rights: A Critical Position on Its Role in a Codified European Contract Law, "European Review of Private Law" vol. 6/2010, p. 1125.

51 J. Cueto-Rua, Abuse of Rights, p. 967-969.

52 M. Byers, Abuse of Rights: An Old Principle, A New Age, "McGill Law Journal" vol. 47/2002, p. 395 and 414 respectively. 
age or harm, 2) when they are exercised without any legitimate or serious interest, 3) when they are exercised against good customs, moral rules or good faith, 4) when they are exercised contrary to the aims for which a given right was designed to. ${ }^{53}$ Michael Byers points out that some of the abovementioned criteria refer to external values (such as good customs, good faith, and aim of the right) - such a phrasing was characteristic for socialist legal systems (and is still present in the Polish legal system, vide art. 5 of the Civil Code or art. 8 of the Labour Code). On the other hand, western European legal systems tend to shorten depend on the specific facts of each case, rather than the application of an abstract legislative standard"56

Therefore, it is unsurprising that this originally domestic institution started gaining influence in the area of international law. Notwithstanding, the status of the prohibition of the abuse of law is still controversial in international law. It is claimed, e.g., that it should be perceived as one of international law's general principles or a part of customary law. ${ }^{57}$ However, doubts are also raised regarding the fact that the concept of the abuse of law is not commonly applied,

\section{Notwithstanding, the status of the prohibition of the abuse of law is still controversial in international law.}

the definition of the abuse of rights, connecting it with the fact of harming another party, or bearing malicious intentions, or both.. ${ }^{54}$

It is noteworthy that the institution of the abuse of rights in municipal legal systems is often connected somehow with the concept of good faith. It is sometimes derived from the former (like in the case of German law), or it replaces the construction of good faith (like in French law). ${ }^{55}$

\subsection{International law}

According to Hersch Lauterpacht:

"only the most primitive of societies could allow the unchecked exercise of rights without regard to their societal consequences, and that the determination of when the exercise of a right becomes abusive must

53 J. Cueto-Rua, Abuse of Rights, p. 985 and following.

54 M. Byers, Abuse of Rights, p. 393-395. Compare also A. Lenaerts (The General Principle of the Prohibition of Abuse of Rights, p. 1127) who distinguishes subjective tests (based on intention) and objective tests (based on effects) of establishing whether the abuse of rights occurred or not.

55 See S. Reinhold, Good Faith in International Law, "UCL Journal of Law and Jurisprudence" vol. 2/2013, p. 42-43. so it cannot be proclaimed as a general principle or element of customary law. ${ }^{58}$ Caveats similar to those issued in the case of domestic legal systems are voiced. Those who oppose the treatment of the institution of the abuse of law as belonging to international law emphasise that it is difficult to distinguish it from rigorous law enforcement. ${ }^{59}$ An uncertain character seems to be an inherent burden of this institution.

Leaving aside these concerns, one should notice that the concept of the abuse of rights is used by international courts, and, moreover, it is directly mentioned in international agreements. ${ }^{60}$ The European Court of Justice refers to it in its judgements, in contrast to the fact, that in European law this principle generally has still an uncodified character. ${ }^{61}$ It should be emphasized that the abuse of rights in international

56 Quoted by M. Byers, Abuse of Rights, p. 406.

57 See M. Byers, Abuse of Rights, p. 397.

58 A. Kiss, Abuse of Rights, p. 3; S. Reinhold, Good Faith in International Law, p. 53.

59 See S. Reinhold, Good Faith in International Law, p. 52.

60 For examples see M. Byers, Abuse of Rights, p. 397 and following; A. Kiss, Abuse of Rights, p. 5 and following.

61 A. Lenaerts, The General Principle of the Prohibition of Abuse of Rights. 
relations can be referred to in the field of both substantive and procedural law. ${ }^{62}$

Alexandre Kiss singles out three possible situations which can be classified as abusive: 1) exercising a right in the way that prevents or makes it more difficult for another country to exercise its rights, 2) exercising a right for the purposes it was not designed to, 3) arbitrarily exercising a right to the detriment of another country. ${ }^{63}$ One can observe that the common feature of all abusive practices, stemming from these three examples, is that the abusing party does not reckon with other parties' interests. The prohibition of the abuse of law aims at mediating between conflicting rights and thus enabling to draw proper boundaries of rights' scope of application. ${ }^{64}$ It should be noticed that in the area of international law, the institution of the abuse of rights plays a certain role not only in state-to-state relations, but also in relationships between international institutions and non-state actors. ${ }^{65}$

Referring once more to the origins of the concept of the abuse of rights in international law, one should pay attention to an older, although similarly controversial institution of good faith. It has a much stronger legal basis than the prohibition of the abuse of law. It is considered to be one of the most important principles of international law and is also widely employed in international treaties, ${ }^{66}$ despite the fact that - just as the abuse of law - it is difficult to define in a fixed manner, with the use of legal terms. ${ }^{67}$ To mention the principle of good faith is crucial in this context,

62 P. Janig, The General Principle of 'Abuse of Rights' and its Application by International Courts and Tribunals With a Special Focus on its Impact on Treaty Shopping in International Investment Disputes, p. 6, accessible: https://ssc-rechtswissenschaften.univie.ac.at/fileadmin/user_upload/s_rechtswissenschaft/Doktoratsstudium_PhD/Expose1/Voelkerrecht/ The_General_Principle_of__Abuse_of_Rights__and_its_ Application_by_International_Courts_and_Tribunals.pdf (last accessed 9.6.2019).

63 A. Kiss, Abuse of Rights, p. 1-2.

64 M. Byers, Abuse of Rights, p. 417 and 429 respectively.

65 A. Kiss, Abuse of Rights, p. 7.

66 S. Reinhold, Good Faith in International Law, p. 40, 59 and following.

67 R. Kolb, Principles as Sources of International Law, p. 13. because it is perceived as an important source of the prohibition of the abuse of law. The latter is considered to be a more precise illustration of the application of the good faith principle, and its concretization. ${ }^{68}$ Should both institutions be split, they would still have the same aims - to protect certain common interests from being supressed by individual ones.

\subsection{Human rights law}

Documents on human rights often contain counter-abusive provisions. As an example we can indicate article 30 of the Universal Declaration on Human Rights (which is the model for other similar statements), article 17 of the Convention for the Protection of Human Rights and Fundamental Freedoms (the European Convention on Human Rights, ECHR), or article 54 of the Charter of Fundamental Rights of the European Union. Though these provisions look very similar, it is worth quoting one of them. Article 17 of the ECHR states the following:

Nothing in this Convention may be interpreted as implying for any State, group or person any right to engage in any activity or perform any act aimed at the destruction of any of the rights and freedoms set forth herein or at their limitation to a greater extent than is provided for in the Convention.

The need to place such a provision in the document on human rights stemmed from the tough historical experiences of its authors, especially the observation that it was by no means a democratic process that the Nazis obtained power in Germany. It demonstrates that rights can be severely misused. ${ }^{69}$ The provision considers the distortion of any rights and freedoms entered into the Convention as a sole criterion of the abuse of rights; the malicious intention of a perpetrator or causing harm is not required in recognising a given practice as abusive. Attempts to apply this principle were undertaken especially in cases concerning racist or xenophobic statements, such as activity of

68 R. Kolb, Principles as Sources of International Law, p. 19.

69 I. C. Kamiński, Ograniczenia swobody wypowiedzi dopuszczalne w Europejskiej Konwencji Praw Człowieka. Analiza krytyczna, accessible: Lex Omega (last accessed 9.6.2019). 
the communists or neo-Nazis. ${ }^{70}$ It did not gain in popularity in the case-law of the European Court of Human Rights, so it is still difficult to derive any fixed and standardized definition of the abuse of law from the Court's approach to the problem. ${ }^{71}$ The Court tends to resolve disputes exclusively on the basis of questioned rights, especially due to fact that many of the provisions guaranteeing them (see articles 8-11 of the ECHR) directly indicate limitation clauses. Hence, according to the Court's stance, there is no need to recall the principle of the abuse of rights. such as good faith, fairness, morality, justice, or the respect of the finality of the law." ${ }^{72}$

She is also right when pointing out that - generally speaking - the importance of this institution is increasing; the prohibition of the abuse of rights spread among different branches of municipal law and international law as well. The institution indicates that there is a "distinction between the existence of an individual right and the exercise of such rights", as Alexandre Kiss concludes. ${ }^{73}$ What needs to be remembered is that the scope of the application of this institution

\section{What needs to be remembered is that}

the scope of the application of this institution

depends on the manner in which legal

provisions are written: the more open-texted

character, the greater risk of its misuse.

Annekatrien Lenaerts convincingly explains that:

"The concept of abuse of rights refers to situations in which a right is formally exercised in conformity with the conditions laid down in the rule granting the right, but where the legal outcome is against the objective of that rule. Thus, the tension between the strict application of a rule and the true spirit of that rule is at stake. In such situations, the principle of the prohibition of abuse of rights functions as a corrective mechanism to the strict application of a rule of law: it will reduce the 'abusive' exercise of the right granted by that rule to a normal use, through reliance on fundamental standards of behaviour,

70 M.A. Nowicki, Komentarz do Konwencji o ochronie praw człowieka i podstawowych wolności, [in:] Wokół Konwencji Europejskiej. Komentarz do Europejskiej Konwencji Praw Człowieka, accessible: Lex Omega (last accessed 9.6.2019).

71 I.C. Kamiński, Ograniczenia swobody wypowiedzi. depends on the manner in which legal provisions are written: the more open-texted character, the greater risk of its misuse. ${ }^{74}$ Due to this, the argument on the abuse of rights can be perceived as useful in the field of strategic litigations, which are mainly based on flexible provisions of human rights treaties.

\section{Application of the abuse of law argument in the area of the strategic litigation}

It is time to consider the potential applicability of the argument based on the prohibition of the abuse of law in the area of strategic litigation. This task requires distinguishing between areas of the substantive law and procedural law, as well as between domestic proceedings and those pending before international courts. The argument of the abuse of law is not applied in actual

72 A. Lenaerts, The General Principle of the Prohibition of Abuse of Rights, p. 1122.

73 A. Kiss, Abuse of Rights, p. 1.

74 See P. Janig, The General Principle of 'Abuse of Rights', p. 6. 
cases very often; hence the following analysis has a more theoretical character and is based on remarks presented in the previous parts of the paper.

It is difficult to make any general remarks when it comes to an analysis of substantive law, simply because cases which are a part of strategic litigation can vary considerably. However, there is one, in my opinion characteristic feature of strategic litigations which gives an opportunity to apply the argument of the abuse of law. It is the fact that such litigations very often employ conflicting rights, rules (also moral or customary), or interests (including private-public interest's conflicts). The proponents of strategic litigation are aware of this problem; ${ }^{75}$ however, they respond to this situation not by giving up such cases, but rather conducting them in possibly a gentle manner, in order to avoid offending parties representing opposite interests. This response is obviously subordinated to achieving predetermined goals, thus having a "strategic" character.

As an example of such a situation - an application of the argument on the abuse of law - we can indicate the case of $D$. and others $v$. Belgium, examined by the European Court of Human Rights. ${ }^{76}$ Claimants held that the Belgian authorities, issuing permissions to bring a child born by a surrogate mother in Ukraine to Belgium, should do it in a timely manner; otherwise, a delay violates (among all) article 8 of the Convention, i.e. the right to privacy. During the proceedings, the abovementioned European Centre for Law and Justice has submitted amicus curiae opinion, raising the argument that a "surrogate pregnancy was contrary to human dignity for both the surrogate mother and the child, and that the practice should be prohibited in all the member States of the Council of Europe". Furthermore the organisation claimed that the applicants themselves created the situation they complained about, so their complaint should be treated as violating article 17 of the Convention. The first observation seems to fit perfectly into the scope of application of the indicated provision - there is a reasonable basis to claim that surrogate motherhood is opposite to the values on which the Convention was

75 Equinet Handbook on Strategic Litigation, p. 31.

76 Application no. 29167/13; the decision on the inadmissibility of the application issued on 8.7.2014. established. Eventually, the Court did not share this view directly; however, it decided the case contrary to claimants' interests, indicating that the lawsuit was manifestly ill-founded.

It is apparent that complaints brought for strategic purposes attempt to exercise rights (already recognised by the courts, or these that are to be created as a result of litigation) against good customs, moral rules, or good faith. These criteria can play an important role on the domestic level of a legal dispute, during the course of evaluating the substantive law basis of the complaint. Noteworthy is the fact that one of the features of abusive conduct is that it does not take into account the interests of others, or rules other than the one recalled as the basis of a lawsuit. There are numerous examples of such practice. The biased interpretation of rights indicated by claimants can lead to absurd results, i.e. deriving the right to death from the right to (worthy) life, the right to have an abortion from procedural guaranties, or the right to have a child from the right to privacy. ${ }^{77}$ The prohibition of the abuse of rights aims at balancing conflicting interests or principles; it helps to avoid the extremist understanding of legal provisions. When it comes to substantive law, it is its mission in the area of strategic litigations.

Chances to apply the argument of the abuse of law to the area of procedural law are even more promising. Especially two criteria from those enumerated by Julio Cueto-Rua can play a significant role here. These are the following: 1) exercising a right without any legitimate or serious interest and 2) exercising a right contrary to the aims for which the right was designed for. Comparing these criteria with purposes assumed by strategic litigators leads to the conclusion that many proceedings initiated for purely strategic reasons can be treated as abusive, because they do not serve the primary goal of the proceedings. Attempts to create new rights, clarify the meaning of legal provisions,

77 To recall only a few examples of remarkable revaluations made recently. Obviously, I am using the term "right" in its colloquial meaning - as a possibility to do something, not in the strict legal sense. See cases: Tysiąc v. Poland (application no. 5410/03, judgement of ECHR delivered on 20 March 2007); Mennesson v. France (application no. 65192/11, judgement of ECHR delivered on 26 June 2014). 
examine a current social or political approach to a certain problem are examples of such conduct. These purposes - frequent in strategic litigations - go far beyond the primary aims of legal proceedings, and, in conjunction with the fact that achieving some of them does not even require winning the trial, demonstrate that the right to a fair trial or the right to complain could be misused in such cases.

Notwithstanding, the practical application of this notion could be difficult. It would not be easy to prove that a legal case was set up not for the reasons declared by its authors. To understand the real intentions of a given motion, the announcements concerning the enrolment of the "friendly victims" could be helpful. They often reveal primary objectives of the NGOs setting up the whole litigation. Also, due to fact that they expressly admit that it is necessary to recruit more than one applicant because the NGO's and claimants' goals can vary ${ }^{78}$ The latter circumstance draws our attention to the next problem - who is, in such proceedings, its real trustee and decision-maker. An actual example of the doubts concerning this question is the case of the so called "Lodz printer", cited above. ${ }^{79}$ The public prosecutor and the defender of the accused in their appeals asked whether the legal person for whom the "real victim" of the accused - natural person - served as a volunteer, could be recognised as the victim in the proceedings.

Naturally, the examining of the question of the "real claimant" can be difficult, but it is not impossible. It is worth recalling the practice of informing the trial parties that they can resign from the legal service of

78 We have to bear in mind, however, that legal provisions very often expressly foresee the participation of NGOs in legal proceedings. Sometimes this participation is restricted to the situation connected with the social or common interest. The question whether the NGO is going to support the general or particular interest should be raised. About strategic litigation`s opportunities of NGOs in Polish law see: J. A. Rybczyńska, M. Płoska-Pecio, Działania prawne $w$ interesie publicznym (litygacja strategiczna) jako forma działania organizacji ochrony praw człowieka, "Annales Universitatis Mariae Curie-Skłodowska Lublin-Polonia Sectio K" vol. 12/2005, p. 99-115.

79 See the judgement of the Łódź District Court delivered on 26 May 2017, V Ka 557/17; more information about the case in the paper is indicated in footnote no. 42. the lawyers, who tend to demand disproportionate salaries in compensation cases, due to irregularities in this area in Polish courts. After it has been demonstrated that legal offices representing claimants in such cases reserve sometimes more than $30 \%$ of the whole amount obtained as a result of the trial, judges often decide to announce this fact to the public prosecutor. This example indicates that courts ex officio, but also as a result of an action of the party to the proceedings, can investigate the relation between a claimant and their supporters. The effects of such an inquiry can bear certain consequences, for example, as far as the motion's admissibility is concerned.

One should bear in mind that the procedural provisions of domestic and international bodies provide us with numerous measures that directly pertain to the institution of the abuse of law, or indirectly refer to the abovementioned criteria singled out by Julio Cueto-Rua. The measures often allow challenging strategic complaints already in the first phase of a litigation. The rules of proceedings before the European Court of Human Rights are a perfect example of such opportunities. The criteria of admissibility of an application are really comprehensive and create a dense structure of positive and negative requirements - also based on merits of a given case - that have to be fulfilled prior to the application's submission. ${ }^{80}$ It is worth pointing out that one of the first instances when the newest admis sibility criterion was employed - "lack of significant disadvantage" - took place before the ECHR in the case concerning neighbours' dispute, ${ }^{81}$ which brings to mind the origins of the idea of the abuse of law.

\section{Further reservations}

In the first part of the paper I referred to doubts concerning strategic litigation and its relations with the principle of the division of powers. The proponents of the concept - which is easily recognisable - tend

80 See European Court of Human Rights Practical Guide on Admissibility Criteria, Strasbourg 2018, accessible: https:// www.echr.coe.int/Documents/Admissibility_guide_ENG. pdf (last accessed 11.6.2019).

81 Daf̌̌e Jancev against the former Yugoslav Republic of Macedonia, ECHR First Section Decision on inadmissibility delivered on 4 October 2011, application no. 18716/09. 
to promote judiciary power at the expense of other powers. It is also not a secret that strategic litigations rely on the particular approach to the profession of the judge, known as judicial activism. The controversy between the doctrine of judicial restraint (passivism) and judicial activism has a long history, and arguments of both sides are very well established. Let me, however, give a reminder of the reasons put forward by the opponents of judicial activism. The arguments are deeply connected with the aforementioned issue of the division of powers. seems to be particularly convincing, as this institution is exclusively designed to bring social change, that is - implicitly - against the will of the majority of society. Therefore, the undemocratic character of the way in which courts, as subjects deprived of democratic legitimacy, affect the shape of legal provisions, is strengthened by the fact that cases being examined are targeted to cause counter-democratic (or at least counter-majority) effects. What is more, due to the specific strategies applied by litigators, it is hard to prove that things are as described above. Litigators

\section{The proponents of the concept - which is easily recognisable - tend to promote judiciary power at the expense of other powers.}

Most commonly, scholars condemning judicial activism claim that courts do not have sufficient democratic legitimization to make laws. (This argument is of course less valid for common law countries). Furthermore, courts lack the appropriate measures to enforce their decisions. Thirdly, courts do not bear responsibility for their decisions - the democratic mechanism allowing changing the decision-maker in the event of their incompetence does not apply here; on the contrary: the judges are irremovable. ${ }^{82}$ All these reservations are accurate when it comes to the problem of strategic litigation; however it is the first argument concerning the lack of democratic legitimacy ${ }^{83}$ that

82 See L. Morawski, Legal policy and courts, [in:] Politics of Law and Legal Policy. Between Modern and Post-Modern Jurisprudence, ed. T. Biernat, M. Zirk-Sadowski, Warszawa 2008 , p. 186-187. It is noteworthy that the third reason could be perceived as well as an argument in favour of judicial law-making; guaranties provided for judges who protect them against undue impacts or sheer opportunism.

83 See H. Duffy, Strategic Human Rights Litigation, p. 2. "Lack of democratic legitimacy" is, of course, a simplification - courts share indirect democratic legitimacy, because it is accepted that they have the right to resolve cases; the problem concerns their right to create law. may for example use a "step-by-step" strategy, which makes it difficult to recognise current social attitudes to a given problem, or even prevents from conducting any comparative research. The following situation may illustrate the problem here: if we were to ask citizens whether it should be legal to pay a strange woman living in a poor country to give birth to a child for another women who pays for it and who would be considered as a mother, it would certainly meet with a social backlash. Strategic litigators do not even attempt to ask such a question, as they are rather inclined to frame the question (and legal problem) in other way, asking different questions instead, such as: should the recognition of personal data documents of a child born abroad be allowed when a child lives with its legal parents? Such an approach is a way to conceal the real - easily foreseeable - intentions of strategic litigators from the court or public opinion. For the opponents of strategic litigations, the application of the slippery slope argument seems to be almost natural - the next step would be to legalise surrogacy in the domestic legal system. However, for a court, sometimes faced with drastic circumstances of a case, it is not as easy. This example - modeled on the Mennesson v. France 
case - shows that the counter-democratic effects of strategic litigations are an actual threat. ${ }^{84}$

There are two aspects left, which in my opinion deepen the problem of the counter-democratic character of strategic litigations. First of all, strategic litigations are not necessarily based on actual social needs. NGOs, often dependent on foreign financial support, select areas, specific problems and finally cases, which are worthy of their attention, rather than provide
The last observation links with notions that are more philosophical than legal. To conclude this part of the paper I should make an attempt at presenting that it is possible to construct a plausible philosophical critique of strategic litigations from both leftist and conservative positions. In order to illustrate the former, I should refer to the famous distinction between instrumental and communicative rationality. In brief, the concept, developed by Jürgen Habermas, assumes

\section{What could undermine the NGOs' efficiency is} the fragmentation of support instead of the focus on one predetermined issue; however, there is still
the problem of non-democratic consequences.

support for those in need. Of course, such an attitude results from the main value of strategic litigations their efficiency. What could undermine the NGOs' efficiency is the fragmentation of support instead of the focus on one predetermined issue; however, there is still the problem of non-democratic consequences. Secondly, apart from the problem of who is the administrator of a lawsuit, strategic litigations usually represent only particular interests. If a court reckons with the side-effects of its decision, an economic or social result seem to be one cause of concern for strategic litigators. They are more inclined to focus on one targeted aspect of the issue in question, than on the analysis of other aspects of the problem, which is the primary duty of the legislator. This feature of strategic litigation has the potential of feeding social tensions due to the win-or-lose character of court disputes. ${ }^{85}$

84 French law directly prohibited the conclusion of surrogate motherhood agreements when the case was examined; see Ł. Mirocha, „Macierzyństwo zastępcze” w aktualnym orzecznictwie Europejskiego Trybunału Praw Człowieka, p. 170 and following.

85 Such a critique of rights-based liberalism and the significant role of the courts that stems from it is for example provided by that social activity can take two forms: 1) target-oriented and governed by technical principles (instrumental rationality), 2) aimed at achieving a consensus, building social bonds (communicative rationality) ${ }^{86}$ Bearing in mind the probable conflicting results of strategic litigation and also the language applied by their proponents ("strategy" as a part of the naming of the whole concept), it is clear that instrumental rationality better reflects the character of the institution under study. It stands at odds with the concept of the "social change" advocated by strategic litigators.

John Gray (see B. Polanowska-Sygulska, John Gray i krytyka liberalnego legalizmu, Kraków 2017, p. 175 and following, especially 202). Of course, we can argue with that vision of the courts' role, especially when it comes to the activity of international bodies, which - pursuant to legal acts governing their activity - have to take into account such values as (e.g.): public safety, public order, morals, rights and freedoms of others (see articles 8-11 of the European Convention on Human Rights).

86 About the leftist brand of J. Habermas and briefly on the commented difference: R. Scruton, Głupcy, oszuści i podżegacze. Myśliciele nowej lewicy, transl. F. Filipowski, Poznań 2018, p. 219 and following. 
The second critical approach - the conservative one - refers to the division between internal goods and external goods of the analysed practices. The concept was developed by Alasdair MacIntyre, a communitarian thinker, but is deeply inspired by the Aristotelian virtue ethics. The essential idea behind this differentiation is that each social practice can be associated with the following: 1) goods that define it, single out the practice from among other practices (internal goods); and: 2) goods that are being subject to a competition and lead to the instrumental use of the practice (external ones). What can be seen as the internal goods of lawyering is the polishing of skills and knowledge in the field of law, or providing people with help to resolve their legal disputes. These goods became common, available for community members; they are characteristic for lawyering as a practice. Pursuant to this point of view, in the case of lawyering, money earned by a lawyer could be considered as external goods. ${ }^{87}$ When we apply these observations into the problem of strategic litigations, we can infer that this sort of litigation is focused on the external goods of the analysed practice - strategic litigators pursue aims that are not necessarily tied to the practice of litigating.

\section{Conclusions}

The paper attempted to analyse the possible results of the encounter of two institutions, stemming from different legal cultures: strategic litigation (brought from the common law system, with its judicial law-making) and the prohibition of the abuse of law (the origins of which date back to the classic civil law regulations).

It cannot be denied that strategic litigation has brought many positive legal and social changes; however, the concept and its implementation are, in my opinion, particularly vulnerable to the risk of misuse of rights. It is hard to resist the impression that strategic litigation, with its rush towards changing established social attitudes or traditions, could be one of the factors accountable for the currently observable

87 See A. MacIntyre, Dziedzictwo cnoty: studium z teorii moralności, transl. A. Chmielewski and others, Warszawa 2007, p. 339. backlash against international courts. ${ }^{88}$ Many countries, protecting their societies' right to self-determination, under the influence of unwanted changes, tend to assert that human rights treaties were not designed to transfer the legislative process from the state's capital cities to international courts. Recent reforms of the European Court of Human Rights, ${ }^{89}$ underlining the value of the subsidiarity principle and limiting the right to individual application in some way, reflect this kind of resistance. As a result, ordinary people struggling with problems, to which the solution could be found before international bodies, can lose valuable opportunities in fighting for their rights, due to, e.g., someone`s desire to buy a child in a foreign country.

\section{Bibliography}

Bodnar A., W poszukiwaniu precedensów - litygacja strategiczna w praktyce Helsińskiej Fundacji Praw Człowieka, [in:] Precedens $w$ polskim systemie prawa, ed. A. Śledzińska-Simon, M. Wyrzykowski, Warszawa 2010.

Byers M., Abuse of Rights: An Old Principle, A New Age, "McGill Law Journal” 2002, vol. 47, issue 2, pp. 390-431.

Cueto-Rua J., Abuse of Rights, “Louisiana Law Review” 1975, vol. 35, issue 5, pp. 965-1013.

Cummings S. L., Rhode D. L., Public Interest Litigation: Insights from Theory and Practice, "Fordham Urban Law Journal “ 2009, vol. XXXVI, pp. 604-651.

Duffy H., Strategic Human Rights Litigation: 'Bursting the Bubble on the Champagne Moment' (inaugural lecture given on 13 March 2017 at Leiden University), accessible: https://openaccess.leidenuniv.nl/handle/1887/59585 (last accessed 31.5.2019)

Equinet Handbook on Strategic Litigation, Brussels 2017, accessible http://equineteurope.org/2019/02/21/strategic-litigation-handbook/ (last accessed 1.6.2019)

European Court of Human Rights Practical Guide on Admissibility Criteria, Strasbourg 2018, accessible: https://www. echr.coe.int/Documents/Admissibility_guide_ENG.pdf(last accessed 11.6.2019)

88 See M. Rask Madsen, P. Cebulak, M. Wiebusch, Backlash against International Courts: Explaining the Forms and Patterns of Resistance to International Courts, "International Journal of Law in Context" vol. 14.2/2018; Strategic Litigation Impacts. Insights from Global Experience, p. 42.

89 See additional protocols no. 14 and 15. 
Goldston J. A., Public Interest Litigation in Central and Eastern Europe: Roots, Prospects, and Challenges, "Human Rights Quartely" 2006, vol. 28, issue 2, pp. 492-527.

Interview with Martin O'Brien, [in:] S. Hansen, Strategic litigation, New York 2018

Janig P., The General Principle of 'Abuse of Rights' and its Application by International Courts and Tribunals With a Special Focus on its Impact on Treaty Shopping in International Investment Disputes, accessible: https://ssc-rechtswissenschaften.univie. ac.at/fileadmin/user_upload/s_rechtswissenschaft/Doktoratsstudium_PhD/Expose1/Voelkerrecht/The_General_Principle_of_Abuse_of_Rights__and_its_Application_by_International_Courts_and_Tribunals.pdf(last accessed 9.6.2019)

Kamiński I. C., Ograniczenia swobody wypowiedzi dopuszczalne w Europejskiej Konwencji Praw Człowieka. Analiza krytyczna, accessible: Lex Omega (last accessed 9.6.2019)

Kiss A., Abuse of Rights, accessible: https://files.pca-cpa.org/ pcadocs/bi-c/1.\%20Investors/4.\%20Legal\%20Authorities/ CA301.pdf (last accessed 9.6.2019)

Kolb R., Principles as Sources of International Law (with Special Reference to Good Faith), "Netherlands International Law Review" 2006, vol. 53, issue 1, pp. 1-36.

Lenaerts A., The General Principle of the Prohibition of Abuse of Rights: A Critical Position on Its Role in a Codified European Contract Law, "European Review of Private Law” 2010, vol. 6.

MacIntyre A., Dziedzictwo cnoty: studium z teorii moralności, transl. A. Chmielewski and others, Warszawa 2007

Mirocha Ł., „Macierzyństwo zastępcze” w aktualnym orzecznictwie Europejskiego Trybunału Praw Człowieka, „Prawo w działaniu" 2018, vol. 34, pp. 164-188.

Mirocha Ł., Polskie orzecznictwo w perspektywie wyroku w sprawie Masterpiece Cakeshop, „Forum Prawnicze” 2018, vol. 2, issue 46 , pp. 65-77.

Morawski L., Legal policy and courts, [in:] Politics of Law and Legal Policy. Between Modern and Post-Modern Jurisprudence, ed. T. Biernat, M. Zirk-Sadowski, Warszawa 2008

Mostowik P., Problem rejestracji w polskich aktach urodzenia pochodzenia dziecka od "rodziców jednopłciowych" na tle orzecznictwa sądów administracyjnych w 2018 r., Warszawa 2019, accessible https://iws.gov.pl/wp-content/
uploads/2019/03/IWS-P.-Mostowik-problem-rejestracji.pdf (last accessed 2.6.2019)

Nowicki M. A., Komentarz do Konwencji o ochronie praw człowieka i podstawowych wolności, [in:] Wokół Konwencji Europejskiej. Komentarz do Europejskiej Konwencji Praw Człowieka, accessible: Lex Omega (last accessed 9.6.2019)

Polanowska-Sygulska B., John Gray i krytyka liberalnego legalizmu, Kraków 2017

Public Law Project: Guide to Strategic Litigation, accessible: https://publiclawproject.org.uk/wp-content/uploads/data/ resources/153/40108-Guide-to-Strategic-Litigation-linked-final_1_8_2016.pdf (last accessed 31.5.2019)

Rask Madsen M., Cebulak P., Wiebusch M., Backlash against International Courts: Explaining the Forms and Patterns of Resistance to International Courts, "International Journal of Law in Context” 2018, vol. 14, issue 2, pp. 197-220.

Reinhold S., Good Faith in International Law, "UCL Journal of Law and Jurisprudence" 2013, vol. 2, pp. 40-63.

Rybczyńska J. A., Płoska-Pecio M., Działania prawne w interesie publicznym (litygacja strategiczna) jako forma działania organizacji ochrony praw człowieka, "Annales Universitatis Mariae Curie-Skłodowska Lublin-Polonia Sectio K” 2005, vol. 12, pp. 99-115.

Scruton R., Co znaczy konserwatyzm, transl. T. Bieroń, Poznań 2014

Scruton R., Głupcy, oszuści i podżegacze. Myśliciele nowej lewicy, transl. F. Filipowski, Poznań 2018

Strategic Litigation Impacts. Insights from Global Experience, New York 2018, accessible: https://www.justiceinitiative.org/ publications/strategic-litigation-impacts-insights-global-experience (last accessed 31.5.2019)

Wilson R. J., J. Rasmusen, Promoting Justice. A Practical Guide to Strategic Human Rights Lawyering, Washington 2001, accessible: http://www.sbdp.org.br/arquivos/material/280_IHRLG_-_ International_Human_Rights_Law_Group_-_Promoting_justice_-_a_pratical_guide_to_strategic_HR_lawyering.pdf (last accessed 31.5.2019)

Załęski P. S., Neoliberalizm i społeczeństwo obywatelskie, Toruń 2012 